\title{
MODEL LAYANAN BIMBINGAN DAN KONSELING UNTUK MENANGANI DAMPAK TRAUMA
}

\author{
Dewi Justitia \\ e-mail: justitiadewi@yahoo.com \\ Bimbingan dan Konseling FIP Universitas Negeri Jakarta
}

\begin{abstract}
Abstrak: Penelitian ini bertujuan untuk mengembangkan model layanan bimbingan dan konseling (BK) pada anak yang trauma akibat kekerasan dalam rumah tangga (KDRT) dengan Art \& Play Therapy. Penelitian dilakukan dalam bulan Maret hingga Mei 2012, pada pelajar SMPN 92 Jakarta. Metode penelitian yang digunakan adalah model penelitian single subject. Berdasarkan penelitian yang dilakukan, diperoleh perubahan berupa penurunan tingkat kecemasan sebagai dampak dari trauma yang diukur dengan menggunakan termometer kecemasan. Pada akhir intervensi diperoleh data bahwa subjek lebih dapat memahami kemunculan KDRT dan memiliki kemampuan untuk menghindari kemunculan kekerasan yang dilakukan ayahnya.
\end{abstract}

Kata kunci: trauma, kecemasan, kekerasan rumah tangga, art and play therapy.

\section{GUIDANCE AND COUNCELING MODEL TO HANDLE TRAUMATIC EFFECT}

\begin{abstract}
The purpose of this study was to develop guidance and counceling model for the children suffering from traumatic effect resulted from domestic violance. Using Art and Play Therapy, this study was conducted in March through May 2012 at Junior Secondary School, No. 92, Jakarta. The research method employed was single subject and it was found out the decrease of traumatic anxiety which was measured with anxiety thermometer. At the end of the intervention, the data showed that the subject got deeper insight of the domestic violance causes and had ability to avoid the violance done by his/her father.
\end{abstract}

Keywords: trauma,anxiety, domestic violance, art and play teraphy,

\section{PENDAHULUAN}

\section{Latar Belakang}

Anak adalah amanah sekaligus karunia dari Tuhan Yang Maha Esa yang sudah selayaknya dijaga dengan baik. Hak asasi anak merupakan hak asasi manusia yang termuat dalam Undang-Undang Dasar 1945. Sedangkan, jika ditinjau dari kehidupan berbangsa dan bernegara anak-anak, adalah generasi penerus cita-cita bangsa, sehingga anak berhak atas kehidupan yang layak, tumbuh kembang yang baik, berhak atas perlindungan dari tindak kekerasan, dan diskriminasi juga, serta pelantaran. Namun pada saat ini, kasus kekerasan pada anak terutama yang terjadi di dalam rumah atau yang biasa disebut kekerasan dalam rumah tangga makin marak terjadi. Orang tua, keluarga inti, dan rumah yang seharusnya menjadi lingkungan yang nyaman bagi tumbuh kembang anak, malah justru mengembangkan trauma tersendiri bagi anak yang menjadi korban kekerasan dalam rumah tangga.

Perlindungan bagi anak korban kekerasan dalam rumah tangga kemudian menjadi suatu hal yang cukup menarik perhatian banyak pihak. Pemerintah mencoba menciptakan Undang-undang untuk melindungi anak dari korban kekerasan dalam rumah tangga. Perlindungan anak korban kekerasan dapat mencakup bentuk perlindungan yang bersifat abstrak (tidak langsung) maupun yang konkret (langsung). Perlindungan yang abstrak pada dasarnya merupakan suatu bentuk perlindungan yang hanya bisa dinikmati atau dirasakan secara emosional (psikis), seperti rasa puas (kepuasan). Sementara itu, perlindungan yang konkret pada dasarnya merupakan bentuk perlindungan yang dapat dinikmati secara nyata, seperti pemberian yang berupa atau bersifat materi maupun nonmateri. Pemberian yang bersifat materi dapat berupa pemberian kompensasi atau restitusi, pembebasan biaya hidup atau pendidikan. Pemberian perlindungan yang bersifat nonmateri dapat berupa pembebasan dari ancaman, serta pemberitaan yang merendahkan martabat kemanusiaan.

Model penanganan konseling bagi anak yang menjadi korban kekerasan dalam rumah tangga saat 
ini banyak dikembangkan oleh praktisi bimbingan konseling karena banyaknya kasus yang merebak belakangan ini. Ada berbagai layanan konseling yang dikembangkan untuk mengakomodasi kebutuhan siswa dengan masalah ini, salah satunya menggunakan layanan konseling kelompok. Kegiatan konseling kelompok bagi anak korban kekerasan dalam rumah tangga bertujuan untuk mengurangi symptom-symptom yang mengganggu perasaan, emosi, kenyamanan, dan tingkah laku anak setelah tindakan kekerasan terjadi pada mereka. Melalui kegiatan konseling kelompok, diharapkan anak-anak yang menjadi korban kekerasan dalam rumah tangga dapat saling berbagi perasaan dengan anak lain yang mempunyai masalah yang sama. Selain itu, anak korban kekerasan dalam rumah tangga dapat meningkat kembali kualitas hidupnya yang setelah terjadi kekerasan mungkin menjadi kurang baik, sehingga berimbas pada perilakunya sehari-sehari. Banyak model terapi yang dapat digunakan untuk menanggulangi trauma pada anak, salah satunya adalah art $\mathcal{E}$ play therapy. Art $\mathcal{E}$ play therapy adalah cara untuk menolong anakanak yang mengalami stres dengan menggunakan permainan sebagai media komunikasi antara anak dan terapis. Dalam terapi ini, konseling akan diajak untuk melakukan permainan-permainan yang dapat membuat konseli mengeluarkan perasaan-perasaan yang tidak terungkapkan. Berdasarkan latar belakang dan identifikasi masalah di atas, maka peneliti akan membatasi masalah pengembangan model penanganan trauma setelah KDRT dengan menggunakan Art $\mathcal{E}$ play therapy.

\section{Rumusan Masalah}

Berdasarkan pada pembatasan masalah dalam penelitian ini, maka perumusan masalah yang akan diteliti, yaitu "Apakah model layanan BK dengan menggunakan art $\mathcal{E}$ play therapy dapat mengatasi masalah trauma akibat KDRT?

\section{Kajian Teori}

A. Kekerasan

\section{Pengertian Kekerasan}

Kekerasan adalah suatu perbuatan terhadap seseorang yang mengakibatkan kesengsaraan atau penderitaan secara fisik, psikologis, seksual, finasial, dan spiritual. Bentuk-bentuk atau dimensi kekerasan adalah dimensi mencakup fisik (memukul, mencekik, dan lain-lain), psikologis (berteriak, mengancam, merendahkan, memaki, dan lain-lain), seksual (menyentuh, meraba, dan lain-lain), finansial (mengambil uang korban, suami tidak memberikan nafkah kepada istri, dan lain-lain), dan spiritual (merendahkan agama lain, dan sebagainya) (Sudarti, 2000). Kekerasan dapat terjadi kepada setiap orang baik orang dewasa maupun anak-anak. Selain itu, kekerasan pun sangat memungkinkan terjadi di mana saja, termasuk di dalam rumah yang seharusnya aman dan menjadi tempat berlindung.

2. Kekerasan Dalam Rumah Tangga

Kekerasan dalam rumah tangga akhir-akhir ini menjadi akrab terdengar di telinga kita. Kekerasan tidak hanya menimpa seorang istri, tetapi juga dapat menimpa pada anak. Belakangan ini juga sering terdengar kekerasan terhadap anak yang dilakukan oleh ibunya sendiri.

Pada konsultasi global tahun 1993, mulai di bahas pengertian kekerasan oleh WHO (World Health Organization). Menurut WHO (1999), kekerasan adalah penggunaan kekuatan fisik dan kekuasaan, ancaman atau tindakan terhadap diri sendiri, perorangan atau sekelompok orang atau masyarakat yang kemungkinan besar mengakibatkan memar atau trauma, kematian, kerugian psikologis, kelainan perkembangan atau perampasan hak.

Menurut Undang-Undang Penghapusan Kekerasan Dalam Rumah Tangga (PKDRT) pasal 1 ayat 1, KDRT adalah setiap perbuatan terhadap seseorang terutama perempuan, yang berakibat timbulnya kesengsaraan atau penderitaan secara fisik, seksual, psikologis, dan/atau penelantaran rumah tangga termasuk ancaman untuk melakukan perbuatan, pemaksaan, atau perampasan kemerdekaan secara melawan hukum dalam lingkup rumah tangga. Lingkup rumah tangga dalam Undang-Undang ini meliputi (Pasal 2 ayat 1): (a) suami, istri, dan anak (termasuk anak angkat dan anak tiri); (b) orang-orang yang mempunyai hubungan keluarga dengan orang sebagaimana dimaksud dalam huruf a karena hubungan darah, perkawinan, persusuan, pengasuhan, dan perwalian, yang menetap dalam rumah tangga (mertua, menantu, ipar dan besan); dan/atau (c) orang yang bekerja membantu rumah tangga dan menetap dalam rumah tangga tersebut (Pekerja Rumah Tangga).

3. Kekerasan Terhadap Anak

Menurut UU Perlindungan Anak pasal 13, yang dimaksud kekerasan terhadap anak adalah diskriminasi, eksploitasi, baik fisik maupun seksual, penelantaran, kekejaman, kekerasan, dan penganiayaan, ketidakadilan, dan perlakuan salah lainnya.

4. Faktor Penyebab Kekerasan Terhadap Anak

Menurut hasil pengaduan yang diterima KomNas Perlindungan Anak (2006), pemicu kekerasan terhadap anak yang terjadi diantaranya: pertama, kekerasan dalam rumah tangga, yaitu dalam keluarga terjadi kekerasan yang melibatkan baik pihak ayah, 
ibu, dan saudara yang lainnya. Kondisi menyebabkan tidak terelakkannya kekerasan terjadi juga pada anak. Anak seringkali menjadi sasaran kemarahan orang tua. Kedua, disfungsi keluarga, yaitu peran orang tua tidak berjalan sebagaimana seharusnya. Adanya disfungsi peran ayah sebagai pemimpin keluarga dan peran ibu sebagai sosok yang membimbing dan menyayangi. Ketiga, aktor ekonomi, yaitu kekerasan timbul karena tekanan ekonomi. Tertekannya kondisi keluarga yang disebabkan himpitan ekonomi adalah faktor yang banyak terjadi. Keempat, pandangan keliru tentang posisi anak dalam keluarga. Orang tua menganggap bahwa anak adalah seseorang yang tidak tahu apa-apa. Dengan demikian, pola asuh apapun berhak dilakukan oleh orang tua.

Disamping itu, faktor penyebab lainnya adalah terinspirasi dari tayangan-tayangan televisi maupun media-media lainnya yang tersebar di lingkungan masyarakat. Yang sangat mengejutkan ternyata $62 \%$ tayangan televisi maupun media lainnya telah membangun dan menciptakan perilaku kekerasan (Tempo, 2006).

\section{Dampak Kekerasan Pada Anak}

Kekerasan yang dialami anak dapat berakibat langsung pada diri sang anak. Bila seorang anak mengalami kekerasan secara fisik, dampak langsung yang akan dialaminya di antaranya dapat mengakibatkan kematian, patah tulang atau luka-luka, dan pertumbuhan fisiknya pun berbeda dengan teman sebayanya. Sedangkan, dampak jangka panjang yang dapat dialami anak yang mendapat kekerasan adalah akan munculnya perasaan malu atau menyalahkan diri sendiri, cemas atau depresi, kehilangan minat untuk bersekolah, stres pascatrauma, seperti terus-menerus memikirkan peristiwa traumatis yang dialaminya, dan dapat pula tumbuh sebagai anak yang mengisolasi diri sendiri dari lingkungan di sekitarnya.

Penelitian McCory dari University College London (Kompasiana, 2012) menyatakan bahwa anakanak yang mengalami KDRT cenderung sangat sensitif dengan ancaman atau sesuatu yang ditakutinya. Bahkan efek yang ditimbulkannya pada otak sama dengan efek yang dirasakan tentara yang bertugas di medan perang. Selain itu, anak-anak korban KDRT sangat rentan terhadap masalah mental seperti stres dan kegelisahan. Selanjutnya McCory menyarankan agar anak-anak yang mengalami KDRT perlu beradaptasi dengan lingkungan yang baru untuk survival. Bantuan agar anak dapat survive di lingkungan baru dapat berupa pemberian layanan konseling untuk memulihkan traumanya (Kompasiana, 2012). Dampak sosial yang juga dialami para anak yang mengalami kekerasan, yaitu selalu curiga dengan orang lain, anak menjadi penyendiri dan menarik diri dari lingkungannya.

B. Konsep Art \& Play Therapy

1. Konsep Dasar dan Urgensi

Art \& Play theraphy adalah teknik yang sistematis dari model teoritis untuk membangun sebuah proses interpersonal, di mana terapis bermain menggunakan kekuatan terapi dari permainan menggunakan media seni seperti gambar dan proses-proses yang kreatif untuk membantu konseli untuk mencegah atau menyelesaikan masalah psikososial dan meraih pertumbuhan dan perkembangan yang optimal (Malchiodi, 2008). Art $\mathcal{E}$ play therapy merupakan bentuk penanganan yang populer untuk anak yang mengalami kekerasan di rumah. Setiap intervensi yang dilakukan dengan anak-anak yang mengalami kekerasan dari keluarganya adalah harus dengan menggunakan kegiatan positif, melibatkan pengalaman sensoris, dan sesuai dengan tahap perkemba-ngan belajar anak. Alasan mengapa digunakannya art $\mathcal{E}$ play therapy secara berkelompok adalah anak usia sekolah, khususnya yang mengalami trauma, lebih memilih untuk menggunakan bahasa nonverbal sebagai alat berkomunikasi untuk mengawali mereka mengungkapkan pengalamannya. Selain itu, anak yang menjadi saksi atau korban dari kekerasan tidak menikmati untuk mengingat kembali trauma karena jika trauma sudah kronis, anak akan menghabiskan sebagian besar hidup mereka untuk mencoba melupakan pengalaman tersebut. Art E play theraphy membolehkan ingatan dan emosi muncul kepermukaan dengan tujuan bahwa anak dapat mentoleransi dan dapat membangun kepercayaan sampai terapi berakhir (Malchiodi, 2008).

\section{Tahapan Art \& Play Theraphy}

Herman (1992, dalam Malchiodi, 2008), seorang ahli trauma dari pelecehan dan kekerasan rumah tangga, mendeskripsikan tiga bagian model pemulihan trauma yang diterapkan untuk mengembangkan konseling kelompok dengan anak yang mengalami kekerasan dalam rumah. Modelnya adalah (1) menumbuhkan rasa aman, (2) bercerita tentang kejadian trauma, dan (3) mengembalikan atau merestorasi hubungan antara individu yang mengalami trauma dan komunitasnya. Dengan sedikit modifikasi, model ini menyediakan struktur yang relevan untuk konseling kelompok dengan anak yang mengalami kekerasan dalam rumah tangga. Tahap pertama, menumbuhkan rasa aman (minggu 1-3), tahap 2: Bercerita tentang pengalaman traumatis (minggu 4-8), dan tahap 3, mengembalikan kepada komunitas (masyarakat) (minggu 9-12) 


\section{METODE PENELITIAN}

\section{Jenis Penelitian}

Berdasarkan metode yang digunakan, penelitian ini termasuk dalam penelitian eksperimen. Metode yang digunakan dalam penelitian ini adalah metode Single Subject Experiment. Dalam sebuah single subject experiment peneliti mengkontraskan beberapa kondisi treatment untuk seorang individu yang perilakunya dipantau secara terus menerus (Shaughnessy, 2007)

\section{Tempat dan Waktu Penelitian}

Penelitian ini dilakukan di SMPN 92 Jakarta Timur pada bulan Maret sampai dengan Mei 2012.

\section{Prosedur Penelitian}

a. Desain Penelitian

Desain eksperimen yang digunakan dalam penelitian ini adalah A-B yang difokuskan pada pemeriksaan terhadap perubahan perilaku pada seorang individu yang berinisial RA. Eksperimen merupakan suatu kegiatan percobaan yang dilakukan untuk meneliti suatu peristiwa atau gejala yang muncul terhadap suatu kondisi tertentu. Penelitian ini menggunakan bentuk desain A-B, yaitu desain penelitian yang memiliki empat fase yaitu, A-1 (baseline-1), B-1 (intervensi-1), A-2 (baseline-2), dan B-2 (intervensi-2) (Shaughnessy, 2007). Desain ini dapat dilihat pada gambar 1.

\begin{tabular}{|l|l|}
$\mathrm{A}$ & $\mathrm{B}$ \\
\hline &
\end{tabular}

Gambar 1. Desain Single Subject Experiment

Fase Baseline (A) : Kondisi dimana intervensi atau treatment belum diberikan

Fase Intervensi (B) : Kondisi dimana perlakuan sedang diberikan

Prosedur penelitian yang dilaksanakan pada desain A-B adalah sebagai berikut: Pertama, menetapkan perilaku yang akan diubah sebagai target behaviour, dalam hal ini yaitu penyesuaian diri siswa dalam hal belajar. Sebelum melaksanakan proses konseling, peneliti mencari data-data tentang konseli yang berkaitan dengan masalahnya. Maka diperoleh deskripsi data konseli, yaitu RA (konseli) adalah salah satu siswa yang tidak naik kelas, RA tidak naik kelas karena sering membolos, tidak memperhatikan guru ketika guru menjelaskan materi pelajaran, tidak mengerjakan tugas dari guru, tidak membawa perlengkapan belajar, seperti buku pelajaran, buku tulis, dan pulpen. Hal ini berdasarkan informasi dari guru BK, dan wali kelas RA.
Kedua, melaksanakan tahap baseline-1 (A-1) untuk mengetahui kemampuan penyesuaian diri belajar siswa yang diukur dengan menggunakan observasi dan angket. Peneliti melakukan observasi dari awal sampai berakhirnya kegiatan belajar mengajar (pukul $12.30 \mathrm{~s} / \mathrm{d} 17.00 \mathrm{WIB}$ ) yang dilakukan oleh observer partisipan dengan menggunakan alat pengumpulan data, yaitu lembar observasi perilaku maladaptif siswa selama 7 hari secara acak di sekolah. Baseline ini dibuat dengan tujuan untuk memperoleh data mengenai frekuensi perilaku maladaptif siswa, dan hasilnya sebagai acuan peneliti untuk menerapkan Konseling Individual.

Ketiga, melaksanakan tahap intervensi (B) dalam bentuk art \& play therapy selama tiga kali pertemuan, yaitu dengan cara sebagai berikut:

1) Menumbuhkan rasa aman

Tahapan ini menekankan kepercayaan dan rasa aman. Anak yang mengalami kekerasan rumah tangga merasa takut dan cemas kepada lingkungan dan anak lain, serta orang dewasa yang tak dikenal, termasuk terapis. Tidak ada anak yang mengalami kekerasan, baik fisik maupun anak yang menyaksikan langsung, akan dapat memulihkan trauma, nyaman dalam berbagi pengalaman dirinya, atau belajar keterampilan baru tanpa perasaan aman. Dalam permulaan sebuah kelompok, dibuat alami. Hal itu sangat penting untuk menumbuhkan rasa aman karena itu akan menentukan tahapan berikutnya dengan menciptakan rasa kepercayaan.

2) Bercerita tentang pengalaman traumatis

Selanjutnya, bercerita tentang pengalaman traumatis yang dialami individu, melibatkan aktivitas untuk mendorong pengalaman personal sharing dan self-disclosure. Selama sesi konseling, anak didorong untuk bercerita tentang bagaimana dampak dari kekerasan dalam rumah tangga terhadap mereka jika mereka nyaman melakukannya. Tujuan keseluruhan dari tahap ini adalah untuk menolong anak yang mengalami kejadian trauma dan memulai untuk mendapatkan kembali kemampuan untuk mengalami dan menikmati hidup meskipun sesuatu yang buruk telah terjadi.

3) Mengembalikan kepada komunitas (masyarakat)

Tahapan terakhir dari pemulihan trauma melibatkan restorasi dari hubungan dengan orang penting dalam kehidupannya. Dalam kasus anak yang telah mengalami kekerasan rumah tangga, hubungan dengan orang tua atau pengasuh yang ramah (tidak kasar) adalah hal yang paling penting dan sentral untuk perbaikan dan pemulihan rasa emosional saat ini maupun pada masa yang akan datang. Untuk 
beberapa orang anggota kelompok, orang tua asuh, pengasuh lainnya, atau bahkan guru mungkin penting untuk kesejahteraan anak saat ini dan masa yang akan datang. Di tahap terakhir ini, orang tua asuh diminta untuk berpartisipasi dalam kelompok di samping anak dalam dua sesi. Dalam praktiknya, partisipasi tersebut memberikan kesempatan pada terapis untuk membantu orang tua belajar informasi tambahan tentang memelihara atau membuat lingkungan rumah yang aman dan stabil untuk diri mereka sendiri dan anak-anaknya. Selama kondisi rumah yang tidak menciptakan rasa aman berlanjut, anak tidak dapat memulai proses pemulihan dari trauma yang disebabkan oleh kekerasan dalam rumah tangga. Pada sebuah sesi dalam tahap ini juga fokus pada pengakhiran terapi kelompok, dan mempersiapkan perpisahan antara anggota kelompok dan terapis. Pengakhiran biasanya sulit bagi anak yang mengalami kekerasan dalam rumah tangga karena pengalaman perlakuan buruk dari orang tua mereka, pengasuh, atau anggota kelompok lainnya.

b. Sumber Data

Populasi yang akan digunakan dalam penelitian ini adalah anak-anak yang mengalami trauma pasca mengalami kekerasan dalam rumah tangga, dan sampel yang akan diambil adalah sebanyak 1 orang anak.

Untuk menentukan sampel yang akan digunakan dalam penelitian ini, teknik yang digunakan adalah Purposive Sampling. Teknik ini adalah sampling yang berdasarkan kepada ciri-ciri yang dimiliki oleh subjek yang dipilih karena ciri-ciri tersebut sesuai dengan tujuan penelitian yang akan dilakukan. Dengan kata lain, teknik penentuan sampel dengan pertimbangan tertentu, dikatakan tertentu karena pengambilan sampel dari hasil rekomendasi guru Bimbingan dan Konseling.

c. Teknik Pengumpulan Data

Untuk memperoleh data dan keterangan yang dibutuhkan dalam penelitian ini, maka peneliti menentukan metode pengumpulan data yang sesuai dengan permasalahan yang diteliti. Pengumpulan data dalam penelitian ini menggunakan:

1. Skala kecemasan,merupakan deretan angkat dari 1 sampai 10 yang menunjukkan tingkat kecemasan yang dirasakan oleh subjek. Makin kecil angka, makin rendah tingkat kecemasan dan sebaliknya.

2. Observasi, merupakan metode atau cara-cara menganalisis dan mengadakan pencatatan secara sistematis mengenai tingkah laku dengan melihat atau mengamati individu atau kelompok secara langsung. Marshall mengemukakan bahwa melalui observasi, peneliti belajar tentang perilaku, dan makna dari perilaku tersebut. Teknik observasi yang digunakan pada penelitian ini adalah observasi sistematis atau terstruktur. Observasi terstruktur adalah observasi yang telah dirancang secara sistematis, tentang apa yang akan diamati, kapan dan di mana tempatnya. Tujuan observasi adalah mengamati subjek penelitian, yaitu sikap dan tingkah laku subjek penelitian sebelum dan setelah proses konseling.

3. Wawancara, merupakan percakapan dengan maksud tertentu. Jenis wawancara yang digunakan adalah wawancara terstruktur, artinya bahwa peneliti menetapkan pertanyaan-pertanyaan yang akan diajukan sebelum dilakukannya proses wawancara. Wawancara ini digunakan sebagai studi pendahuluan untuk menemukan permasalahan yang harus diteliti. Tujuan dari wawancara ini adalah untuk memperoleh data yang akurat mengenai riwayat hidup subjek penelitian, kegiatan sehari-hari subjek penelitian, dan sikap subjek penelitian dalam kegiatan pembelajaran di kelas. Sebagai data empiris mengenai karakteristik dan keadaan subjek penelitian dari sebelum terapan pendekatan behavioral (token ekonomi dan pengaturan diri) selama terapan hingga akhir konseling. Hal ini dimaksudkan untuk mengetahui apakah ada perubahan positif dari subjek penelitian dalam kegiatan pembelajaran, yaitu pada akhirnya akan menghasilkan penurunan perilaku maladaptif siswa di sekolah.

\section{d. Teknik Analisis Data}

Analisis data merupakan tahap terakhir sebelum penarikan kesimpulan. Single subject experiment difokuskan pada pemeriksaan terhadap perubahan perilaku pada seorang individu atau paling banyak beberapa orang individu. Menurut Juang (2000:21), bahwa penelitian dengan single subject research, yaitu penelitian dengan subjek tunggal dengan prosedur penelitian menggunakan desain eksperimen untuk melihat pengaruh perlakuan terhadap perubahan tingkah laku. Data dianalisis dengan menggunakan analisis visual grafik (visual analisis of grafik data), yaitu dengan cara menyimpan data-data ke dalam grafik, kemudian data tersebut dianalisis berdasarkan komponen-komponen pada setiap kondisi (A dan B), dengan langkah-langkah sebagai berikut.

Pertama, Analisis dalam kondisi, maksudnya adalah data grafik masing-masing kondisi, dengan langkah-langkah : (1) menentukan panjangnya kondisi, (2) menentukan estimasi kecenderungan arah, (3) menentukan jejak data, dan (4) menentukan level pe rubahan 
Kedua, analisis antar kondisi. Juang (2005:117) mengatakan untuk memulai menganalisa perubahan data antar kondisi, data yang stabil harus mendahului kondisi yang akan dianalis, karena jika data bervariasi (tidak stabil) maka akan mengalami kesulitan untuk menginterpretasi. Selain aspek stabilitas ada tidaknya pengaruh intervensi terhadap variabel terikat juga tergantung pada aspek perubahan level dan besar kecilnya overlap yang terjadi antara dua kondisi yang dianalisis.

\section{HASIL DAN PEMBAHASAN}

Pada subbab ini peneliti membahas dan menguraikan hasil penelitian yang telah dilakukan. Penelitian ini dilakukan pada siswa kelas VIII yang berinisial TNR di SMP Negeri 92 Jakarta Timur yang telah terpilih secara purposive (bertujuan).

1. Deskripsi Data

Hasil rekapitulasi perolehan data dari konseling individu menggunakan art theraphy dapat dilihat pada tabel 1.

Tabel 1. Hasil Rekapitulasi Perolehan Data Dari Konseling Individu Menggunakan Art Theraphy

\begin{tabular}{|l|l|l|}
\hline \multicolumn{1}{|c|}{ Baseline dan Intervensi } & $\begin{array}{c}\text { Rata-rata tingkat } \\
\text { kecemasan yang } \\
\text { dirasakan Subjek }\end{array}$ & $\begin{array}{c}\text { Persentase } \\
(\%)\end{array}$ \\
\hline A. (Baseline) & 3.66 & $86 \%$ \\
\hline $\begin{array}{c}\text { B. (intervensi dengan } \\
\text { menggunakan art \& } \\
\text { theraphy) }\end{array}$ & 0.5 & $13.2 \%$ \\
\hline
\end{tabular}

Keterangan :

- Baseline (A) : Kondisi dimana intervensi atau treatment belum diberikan.

- Intervensi (B): Kondisi dimana perlakuan/treatment sedang diberikan.

\section{Baseline (A)}

Data hasil pengukuran pada baseline (A), yaitu sebelum intervensi dilakukan, diperoleh angka rata-rata yang cukup besar, yakni 4.33. Hari pertama, tingkat kecemasan subjek diukur termometer kecemasan. Hasilnya tingkat kecemasan subyek berada pada angka 4. Angka ini menggambarkan bahwa subyek sedang mengalami kecemasan dan kemarahan dengan obyek kemarahan adalah ayahnya. Hari kedua, subjek berada pada angka 3, artinya terjadi penurunan kecemasan, tetapi masih cemas. Memasuki hari ketiga, tingkat kecemasan kembali naik, berada pada angka 4. Terjadi fluktuasi tingkat kecemasan, meskipun sedikit. Untuk memudahkan dapat dilihat pada tabel 2.
Tabel 2. Tingkat Kecemasan Responden

\begin{tabular}{|c|c|c|}
\hline Baseline (A) & \multirow{2}{*}{ Tingkat Kecemasan } & Persentase (\%) \\
\cline { 1 - 2 } Sesi & 4 & $100 \%$ \\
\hline 1 & 3 & $75 \%$ \\
\hline 2 & 4 & $100 \%$ \\
\hline 3 & 3.66 & $91.5 \%$ \\
\hline Rata-rata & &
\end{tabular}

Intervensi (B)

Intervensi yang dilakukan adalah dengan menggunakan art theraphy. Kegiatannya berupa menggambar. Konseli diminta untuk menggambar sebagai bentuk ekspresi perasaan serta kecemasan-kecemasan dan trauma yang dialami. Tak hanya itu, sebagai tambahan juga diperbolehkan untuk mengekspresikan perasaan-perasaannya melalui tulisan-tulisan. Pelaksanaan art theraphy dilakukan sebanyak 3 kali dan dilaksanakan pada hari yang berbeda. Setelah selesai mengambar, konseli diukur menggunakan termometer kecemasan. Pada hari pertama, tingkat kecemasan konseling berada pada level 2, sedangkan pada hari kedua dan ketiga tingkat kecemasannya berada pada angka 0 . Tampak terlihat bahwa tingkat kecemasan konseli secara berangsur menurun bahkan menghilang. Secara sederhana deskripsi data di atas dapat dilihat pada tabel 3.

Tabel 3. Tingkat Kecemasan Pasca Intervensi

\begin{tabular}{|c|c|c|}
\hline Baseline $(\mathrm{A})$ & \multirow{2}{*}{ Tingkat Kecemasan } & Persentase (\%) \\
\cline { 1 - 2 } Sesi & 2 & 50 \\
\hline 4 & 0 & 0 \\
\hline 5 & 0 & 0 \\
\hline 6 & 0.5 & 12.5 \\
\hline Rata-rata & &
\end{tabular}

\section{Pelaksanaan Proses Konseling}

Proses konseling yang telah dilakukan kepada subjek untuk menurunkan kecemasan terhadap ayahnya dilakukan melalui tahapan-tahapan seperti tertera pada tabel 4 .

Tabel 4. Tahapan Pelaksanaan Konseling

\begin{tabular}{|c|l|}
\hline \multicolumn{1}{|c|}{ Pelaksanaan } & \multicolumn{1}{|c|}{ Kegiatan } \\
\hline Intervensi Pertama & Perkenalan \\
\cline { 2 - 2 } & Membangun rapport \\
\hline Intervensi Pertama & $\begin{array}{l}\text { Verbal setting (kerahasiaan, aturan main, } \\
\text { kerjasama, dan kebersamaan) }\end{array}$ \\
\cline { 2 - 2 } & Aktivitas penggalian perasaan \\
\hline & $\begin{array}{l}\text { Minta konseli menuliskan perasaan-pe- } \\
\text { rasaan di selembar kertas dan dibentuk } \\
\text { burung atau kapal } \\
\end{array}$ \\
& $\begin{array}{l}\text { Membuat gambar skala kecemasan (ter- } \\
\text { mometer dengan skala 1 sampai 10) }\end{array}$ \\
\hline
\end{tabular}




\begin{tabular}{|c|c|}
\hline Pelaksanaan & Kegiatan \\
\hline & $\begin{array}{l}\text { - Konseli diminta mengidentifikasi pera- } \\
\text { saan-perasaannya kemudian menter- } \\
\text { jemahkan dalam bentuk gambar. Setelah } \\
\text { itu konselor menggali perasaan yang } \\
\text { dialami konseli dengan pertanyaan (apa } \\
\text { yang kamu rasakan, bagaimana reaksi } \\
\text { kamu, di mana, bersama siapa, ceritakan } \\
\text { kembali, seperti apa, dll). } \\
\text { - Setelah itu konselor mendiskusikan } \\
\text { gambar tersebut. }\end{array}$ \\
\hline & - Lakukan relaksasi bila memungkinkan \\
\hline \multirow[t]{9}{*}{ Intervensi Kedua } & Membangun rapport \\
\hline & Verbal setting \\
\hline & Ice breaking \\
\hline & Aktivitas penggalian perasaan \\
\hline & $\begin{array}{l}\text { - Mereviu pertemuan sebelumnya } \\
\text { - Mendiskusikan usaha-usaha yang } \\
\text { dilakukan untuk mengatasi perasaan } \\
\text { negatif } \\
\text { - Konseli diminta menggambar keluarg- } \\
\text { anya, apa yang terjadi di dalam keluarga } \\
\text { (kekerasan, perilaku kasar, atau kejadian } \\
\text { trauma lainnya) dan menggambar apa } \\
\text { yang dapat membuat keadaan keluarga } \\
\text { lebih baik (masa depan yang lebih baik) }\end{array}$ \\
\hline & $\begin{array}{l}\text { - Menggambar "siapa/apa yang membuat } \\
\text { dirinya cemas (takut atau marah) sejak } \\
\text { itu terjadi }\end{array}$ \\
\hline & $\begin{array}{l}\text { - Konseli diajarkan mengenai negatif dan } \\
\text { positif self-talk dan berlatih untuk me- } \\
\text { ngurangi pikiran negatif }\end{array}$ \\
\hline & $\begin{array}{l}\text { - Membuat termometer skala mengenai } \\
\text { perasaan yang sedang dirasakan } \\
\text { - Menggambar bebas untuk mengekspre- } \\
\text { sikan perasaan } \\
\text { - Lakukan relaksasi atau aktivitas yang } \\
\text { dapat mengurangi stres dan mengiden- } \\
\text { tifikasi letak kecemasan dan perasaan } \\
\text { yang tidak nyaman }\end{array}$ \\
\hline & $\begin{array}{l}\text { - Minta konseli menuliskan perasaan-pe- } \\
\text { rasaan di selembar kertas dan dibentuk } \\
\text { burung atau kapal } \\
\text { - Membuat gambar skala kecemasan (ter- } \\
\text { mometer dengan skala } 1 \text { sampai 10) } \\
\text { - Konseli diminta mengidentifikasi pera- } \\
\text { saan-perasaannya, kemudian menter- } \\
\text { jemahkan dalam bentuk gambar. Setelah } \\
\text { itu, konselor menggali perasaan yang } \\
\text { dialami konseli dengan pertanyaan (apa } \\
\text { yang kamu rasakan, bagaimana reaksi } \\
\text { kamu, di mana, bersama siapa, ceritakan } \\
\text { kembali, seperti apa, dll). } \\
\text { - Setelah itu, konselor mendiskusikan } \\
\text { gambar tersebut. }\end{array}$ \\
\hline \multirow[t]{2}{*}{ Intervensi Ketiga } & - Membangun rapport \\
\hline & - Verbal setting \\
\hline \multirow[t]{2}{*}{ Intervensi Ketiga } & $\begin{array}{l}\text { - Sharing dengan konselor mengenai hal-hal } \\
\text { apa saja yang telah didapatkan selama } \\
\text { terapi berlangsung }\end{array}$ \\
\hline & $\begin{array}{l}\text { - Menginstruksikan konseli untuk meng- } \\
\text { gambarkan masa depannya } \\
\text { - Membuat termometer skala mengenai } \\
\text { perasaan (kecemasan) yang sedang } \\
\text { dirasakan untuk dibandingkan dengan } \\
\text { gambar yang dibuat di sesi sebelumnya }\end{array}$ \\
\hline
\end{tabular}

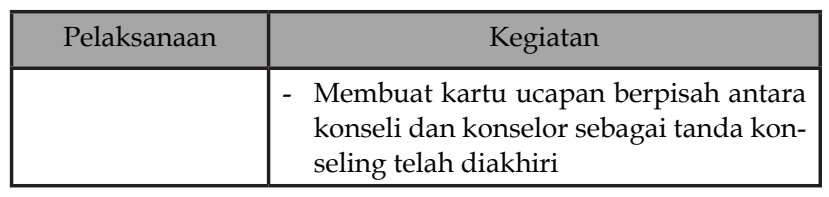

\section{PENUTUP}

\section{Kesimpulan}

Pelaksanaan artE play therapy pada kasus cemas yang disebabkan oleh trauma karena kekerasan dalam rumah tangga (KDRT) dalam penelitian ini memberikan hasil yang signifikan. Tingkat kecemasan yang selama ini tinggi, mengalami penurunan yang bermakna. Kecemasannya menjadi turun dan bahkan pada akhir sesi terapi, subjek tampak dapat menerima keadaan bapaknya, serta apa yang menyebabkan terjadinya KDRT yang dialaminya.

Pelaksanaan art $\mathcal{E}$ play therapi dilakukan sebanyak 6 kali pertemuan. Pertemuan dibagi dua bagian: 3 pertemuan tahap penggalian data dan tahap sisanya adalah intervensi. Pada awalnya, subjek ekpresi yang muncul adalah kesedihan, tampak tertekan, dan ketakutan. Bahkan pada sesi atau pertemuan ke 3 ,konseli sempat menagis tersedu-sedu, dan tingkat berdasarkan skala kecemasan berada pada angka. Pada sesi berikutnya, subjek tampak terlihat senang, bahagia, dan iri. Senang dan bahagia di sini yaitu karena subjek sedang dekat dengan seseorang, yaitu laki-laki yang sudah dianggapnya seperti kakaknya sendiri. Hari itu, orang yang ia sebut 'abang' menjanjikan akan memberikannya hadiah. Subjek belum tahu persis dalam rangka apa abangnya tersebut akan memberikan hadiah, tetapi karena itu adalah abangnya, maka rasa senang dan bahagia. Rasa iri yang subjek alami yaitu karena ayahnya membela adiknya, padahal saat itu adiknya yang salah, tetapi subjek justru ikut disalahkan. Hal tersebut juga tercermin dari gambarnya, yaitu mencerminkan keinginan agar ayahnya berlaku adil. Kemudian untuk gambar bebas, subjek menggambarkan harapan-harapannya terhadap ayahnya. Sedangkan saat diminta untuk menyebutkan skala kecemasannya terhadap ayahnya, subjek memilih dua yaitu cukup cemas.

Secara umum, perubahan yang terjadi pada subjek setelah pelaksanaan art $\mathcal{E}$ play therapy adalah pertama, subjek lebih tenang atas apa yang sebelumnya dirasakan, yaitu kecemasannya. Kedua, lebih mengerti keadaan orang tua, baik dari segi ekonomi, maupun yang lainnya. Hal ini termasuk mengapa ayahnya bersikap keras. Subjek sekarang menyadari bahwa jika subjek tidak menuruti ayahnya, maka yang terjadi adalah ayahnya semakin marah dan kekerasan itu terjadi terus-menerus. Sedangkan jika subjek menu- 
ruti ayahnya maka ayahnya pun akan bersikap baik kepada subjek

\section{Saran-saran}

Berdasarkan penelitian yang dilaksanakan beberapa saran yang dapat diberikan antara lain: pertama, penggunaan art $\mathcal{E}$ play therapy secara umum lebih mudah untuk dilakukan karena prosedur pelaksanaan yang sederhana dan memberikan peluang kepada subjek untuk mengekplorasi perasaannya. Kedua, untuk peneliti lain diperlukan penelitian dengan metode yang berbeda untuk mengujikan tingkat efektifitas dari art $\mathcal{E}$ play therapy sehingga akan lebih terujikan kemanfaatannya bagi konseli.

\section{DAFTAR PUSTAKA}

Arifin, Z. (2011). Penelitian pendidikan. Bandung: PT. Remaja Rosda Karya.

Herdiansyah, H. (2011). Metodologi penelitian kualitatif untuk ilmu-ilmu sosial. Jakarta: Salemba Humanika.

Malchiodi, A.C. (2008). Creative intervensions with traumatized children. The Guild Ford: New York

Shaughnessy, J.J. (2007). Metodologi penelitian psikologi. Yogyakarta: Pustaka Pelajar.

Sugiono. (2009). Metode penelitian kuantitatif kualitatif dan $R \mathcal{E} D$. Bandung: Alfabeta.

Sunanto, J. (2005). Pengantar penelitian dengan subyek tunggal. Universitas Tsukuba: Criced. 